\title{
GEORGE ORWELL'S PESSIMISTIC VISION OF 1984 OR FRANCIS FUKUYAMA'S OPTIMISM: THE FUTURE OF HIGHER EDUCATION EXEMPLIFIED BY BRITISH UNIVERSITIES
}

\author{
Marek Smoluk \\ Zielona Góra University, Poland
}

\begin{abstract}
A new report on higher education, which marks the 50th anniversary of the Robins Report, reveals that academics, instead of devoting more time to teaching, actually prioritise their research. Further, it is claimed that two-thirds of students receive no feedback. These findings have been publicised in a pamphlet which at the same time, discloses new predictions, including a huge increase in the number of university entrants by 2035. The analysis of these findings, confronted with subsequent reasoning which may have caused them, should allow the establishment of the present trends that have been formed in higher education and are bound to be followed; especially by the 'newer' United Kingdom universities. Thus this paper's main aim is to identify possible challenges and pitfalls which may well await these universities in the future. Also, such an evaluation becomes quintessential in view of the fact that at present students' fees have risen to circa $£ 9,000$-10,000 for the very same courses which were available at the time when such tuition was free. The paper provides evidence that the underlying reason for many of the present problems these 'less prestigious' universities are experiencing, is chronic under-funding. As the current pattern of expansion appears to be occurring even more speedily than expected, one needs to bear in mind that distortion usually results when such goals wish to be achieved with a minimum effort and more importantly, at minimum possible cost.
\end{abstract}

Keywords: higher education, British universities, future of higher education 
My plenary lecture delivered in Vienna in September 2013 during the Academic Fiction in Anglo-American perspective research seminar was entitled Current Expansion and Distortion of Higher Education in the United Kingdom and it focused on drawing an outline of higher education from its most remote times to the present day (Smoluk 2014: 17-24). On the basis of this history, analyses show how through the centuries (recent decades in particular) higher education has expanded and led to numerous misappropriations and misunderstandings in the use of the expressive "higher" education. The following presentation entitled Modularisation and Commodification of Higher Education in the United Kingdom was delivered last year at the University of Bucharest and it referred mainly to the identification of merits and demerits of the modular degrees and credit accumulation programmes and subsequently, the evaluation of their impact on 'commodifying' education. As the past and present assessment of higher education has already been presented, and in order to make this series complete, the 2nd International Conference on Education, Culture and Identity, held at the International University of Sarajevo in October 2015, has enabled me to talk on recognition of these modern trends which influence universities these days and which require examination in order to provide a basis for speculation on the challenges and dangers awaiting higher teaching institutions in the future.

When over a hundred years ago a few British universities began to introduce new courses as subjects of study for a degree such as English literature or later, engineering, these decisions on the extension of subjects offered by universities were regarded as pioneering. Not in wildest dreams was it thought then, that over the forthcoming century the curriculum would be expanded and revolutionised by the inculcation of courses in genetics, biotechnology, microbiology, business studies, management studies or computer science, et cetera. The above examples illustrate that making certain predictions for what a university ought to look like half a century ahead poses a major risk of misjudgment and invites errors. Anything may happen and as Hans Van Ginkel, Rector of Utrecht University, notes, the future of universities can follow either George Orwell's pessimistic vision of 1984 or Francis Fukuyama's optimism, and, whichever version proves correct, this will be determined by changes in society, "both at an economic level and in socio-political terms" (Ginkel 1994: 67). Allowing for the foregoing, this paper does not attempt to speculate whether future universities will have few buildings and that such teaching will be carried out by international networks - symptoms of which are already risibly visible by the setting up of more and more popular distant teaching institutions. Neither is its aim to ascertain whether universities will be confined to a "barracks" in which lecturers, researchers and scholars will continue their work. Instead of drawing unpredictable visions, the paper's aim is to recognise present tendencies 
whereby higher education evolves and - as already mentioned - on such bases make pertinent speculations apropos possible challenges and pitfalls.

Consequently, this should help us to reflect and possibly prevent those in authority from making decisions that may, in the long run, turn out to be harmful for higher education.

One of the trends referring to future higher education was formed with the acceptance of the Dearing Report of 1997, in which, amongst numerous recommendations, this one stated that over the next twenty years a steady increase in student numbers should be secured. This government's declared policy has proven very successful as by the year 2000 the number of students had more than doubled (Gombrich 2000: 10) and within the last ten years this figure has risen by $25 \%$ to 2,5 million students, both undergraduates and postgraduates. Prospects for the future are even more optimistic. In a report revealed on behalf of the Social Market Foundation think tank in October 2013 David Willetts, Minister for Universities and Science, appears to anticipate a steep increase in the number of students entering higher education by 2035 due to rising birth rates, as well as growing interest of the young in getting a university education. According to Mr Willetts, these demographic and social changes will result in 460,000 young entrants entering universities every year by 2035, which is up by a quarter from 2011 (Graham 2013:6). Such an anticipated increasing rise in demand for places at British universities is much in tune with the government's commitment to guarantee that every "motivated and qualified applicant is offered a place in a UK university" (Graham 2013:6).

Laudable - in its very essence - as this expansion of university students sounds, the trend lays out pitfalls for future and may bring about considerable distortion in the idea of higher education.

With tuition fees skyrocketing during the last few years, a fundamental question arises what this average $£ 9,000$ + gets for a potential student? The pamphlet, which has been published recently for the Social Market Foundation to mark the 50th anniversary of the Robbins report on higher education, reveals sensational findings. These can be useful when answering the above question. According to this study commissioned by the Department for Business, present lecturers at red-brick universities, it is claimed, spend 40 per cent of their time teaching and 60 per cent "facilitating" research, whilst half a century ago the ratio was almost the opposite: 55 per cent was spent on teaching and 45 per cent on research (Garner 2013: 2).

It becomes self-evident that the proportion of total academic time devoted to teaching has shrunk significantly and such figures should be viewed with a meas- 
ure of caution, especially when contrasted with the growth in the number of students at these universities. The less time devoted to lecturing is not the only notable decreasing figure in this report. Another finding refers to the average time spent by students being taught; this has dropped from 14.8 hours a week to 12.2 - with an increasing number of lectures conducted in auditoriums with up to one hundred students (Garner 2013: 2). Last but not least an horrific figure relates to written assignments. In 1963 the average student would usually hand in one piece of written work. At present this has fallen to one a fortnight. Not only in the quantity of assignments but also in the quality of feedback, universities are lagging far behind the times compared with a century ago; nowadays 77 per cent of written work is handed back to students with only written feedback and a grade, whilst in 1963, 61 per cent of more frequent assignments received both written comments and oral feedback (Garner 2013: 2). Figures released in the pamphlet indicate one more trend of England's present higher education: undergraduates assignment papers are usually marked as pass or fail, and there is little chance that they would be of any constructive feedback since their essays or projects are usually handed back when the students have moved on to the next module (Hussey, Smith 2010:35).

In view of such findings released recently, it should not be surprising to hear why students' parents keep asking more and more insistently questions such as "Do you really only get three hours of lectures a week? How much time do you spend in the lab? What do you mean you haven't sat down with any of the professors yet?" (Garner 2013: 2). Questions of this calibre are perfectly understandable, but who and/or what should be blamed for having such issues raised?

The title of Richard Garner’s article What the $£ 9,000$ fee gets you: less teaching time prompts the reader to a straight answer: it is the academics who ought to be blamed for teaching less and worse than was done half a century ago. Are these recriminations which are claimed to echo in English society, substantiated and do they truly reflect the current state of higher education in the United Kingdom?

As student contact time is reported to have decreased in the last fifty years, it should be remembered that the gigantic rise in student numbers within the last few decades has not been matched by a proportional increase in teaching/lecturing staff. Due, simply, to lack of proportions maintained, current academics seem to be buried under administration and paperwork, which, in fairness, their colleagues of the 1960s were perhaps lucky enough to do without, or at least not in such volume. This additional burden on the lecturers' shoulders is well described by Professor Pete Dorey who writes: 
The Soviet-style managerialist regime imposed on universities by successive governments means many academics spend up to $40 \%$ of their time on form-filling, box-ticking, business plans, quality assurance frameworks and countless 'strategy' meetings or reviews (Dorey 2013: 39).

In light of teaching staff-student ratios becoming reversed during the periods under discussion, and this coupled with a "different" kind of paperwork, increasing substantially now, but virtually non-existent half a century ago, present claims of decreasing student contact time and less effective feedback, even if correct, have their justification in the different circumstances in which universities were operating in the 1960's compared with the present.

Another finding of the recent study reveals that academics place the priority of facilitating research over lecturing. It is suggested that they should 'tuck' this part of work into their spare time so that their main mission of teaching is not affected. The Report, however, does not mention that according to the Research Excellence Framework (REF) - formerly the Research Assessment Exercise (RAE) introduced by the Thatcher government, academics are under obligation to do research. First, only such academics who are active in research can feel competent enough to prepare course syllabuses which enable them to examine their students and finally to award appropriate degrees for the graduates. Second, not only does research enrich students' experience but it also exposes researchers and their students to global challenges, which consequently, may transform our lives beyond recognition. Third, from the universities' viewpoint, research is co-related to international prestige and league table rankings and above all such scholarly activity determines, to a large extent, the funding available to the departments. Last but not least a crucial factor is that career progression depends on one's research results. Whether an academic is promoted or made redundant will be dependent upon his/her devotion and research 'outputs' (Dorey 2013: 39).

In view of the above, the question arises whether less time devoted to teaching and more to research is as a result of teachers' negligence or simply a consequence of the circumstances in which the "collective" responsibility for higher education has voluntarily or indeed in-voluntarily cornered itself?

According to Sally Hunt, General secretary of University and College Union, the primary function of a university is "to produce well-rounded, engaged individuals able to reason and question. That capacity makes someone employable, but it also makes them a more engaged citizen too" (2013: 39). It should be added at this point that it is assumed the aim of higher education lies in its mission not only to educate the young but also to facilitate research, both to the highest standards. In 
order to be able to both maintain and improve these standards, clearly adequate funding is required. Like in any typical household, one should buy such chattels or get involved in such financial enterprises which are at least affordable. The UK governments, running this 'household' on a macro level, seem to have overlooked this maxim and throughout the last century, have launched four waves of higher education expansion. First, by the nineteen twenties, in the period of the 'redbricks' foundations, the already existing number of universities in the kingdom increased to just over twenty. The era of the Robbins Report (1960s) more than doubled this number. The third wave of university expansion came with the passage of the Further and Higher Education Act of 1992 which permitted all polytechnics to become universities. The new Millennium ushered in another period of thirty six polytechnics, colleges and higher education institutes receiving university status, thus all in all there are about 120 universities in the United Kingdom, out of which 78 are in England alone.

This recent rapid growth in the size of the educational sector and its beneficiaries i.e. students, has not gone along with their adequate financial support. As a result of the policies of successive governments, the $90 \%$ cut in teaching budgets imposed by the government is supposed to be offset by the $£ 9,000+$ fees. Not in even the most pessimistic visions promulgated in 2006, did anyone anticipate that

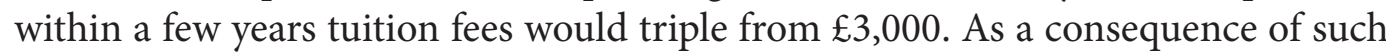
policies, not only for a student in England has a university education become the most expensive in Europe, but more sadly these higher teaching institutions have, on the pretext of modernisation, been compelled to act as competitive corporate enterprises. As competition is a discipline of the market economy, this economic rule, it was thought, could be applied to universities. It was argued that thanks to the application of competition, teaching institutions would be encouraged to make more effort towards self-maintenance and if their performance was still unsatisfactory, this could call for reforms, and finally, if they still could not get their act together, this would force them to suffer the consequences by closing down the ineffective ones. In the world of academic competition, effectiveness and the efficiency of teaching institutions are now measured in part by the number of applicants who are admitted to studies, and this, in turn, determines their Treasury Grant. The irrational thinking behind the turning of the higher education system 'upside down' was that potential students were believed to obtain a wider choice of being educated at lesser cost incurred by the taxpayer. This was - as Hussey and Smith call it - 'the political equivalent of turning base metals into gold' (2010: 3).

What was, however, overlooked in the whole operation was one tiny nuisance i.e. there is a huge discrepancy between for instance companies making and selling paper and universities which buy and use this paper for facilitating research and im- 
parting knowledge. With the competition wheels being set in motion in the 1980s, the survival race and more and more frustrating struggle for finances at universities had begun. The side effects of this university revolution are countless. Suffice it to say, universities use all possible tricks in order to attract students and once they get hold of new entrants, they are prepared to do their utmost to smooth their passage through the system. Should any student fail an examination, the regulations allow for a number of solutions so as to prevent him from dropping out. This has already given rise to the dumbing down of traditional degrees. As a result, what is achieved is not what is desired: illiterate and incompetent graduates with "Mickey Mouse" degrees, which are given away by - as B. Brecher (2002: 18) and other scholars (S. Baker, Brian J. Brown 2007: 124) call them - "Disneyland" universities.

Has anyone in authority given any thought if it is a mere coincidence, or does some correlation exist between a growing number of students who graduate from universities with first class honours, and an increasing number of prospective employers who point to cases of illiterate and incompetent graduates, who have to be trained from scratch before they are capable of work? One can feel less remorse if the re-training of a supposedly qualified graduate should be practical or even possible, but who should take the responsibility for allowing a graduate who himself lacks knowledge and thus imparts scraps of information in a haphazard way to young children at school? Thus in this context, what many claim that "the whole thing is too expensive and inefficient and that it is educating the wrong people in the wrong way and for the wrong jobs" (Hussey, Smith 2010: 35) seems to have appalling examples of such inexcusable practices in real life.

From the above it becomes self-evident that what we witness is confused decadence in higher education, but the question remains; to what is this decline due? The pamphlet recently published for the Social Market Foundation and mentioned here several times, reveals, amongst other findings, an increasing number of lectures that are run in auditoriums with up to one hundred students (Garner 2013: 2). This should not come as a surprise why universities with their cash-stripped budgets take such measures. Clearly, it has become economically viable to teach - or rather lecture - large groups since this method saves a lot of teaching hours which would have to be paid for if the teaching took place in smaller groups. Thus the struggle of academics to provide a good quality education has been replaced with their struggle for survival.

For the sake of argument, should we take the assumption that all the successive governments from the 1960s to the present day have had a clear vision of how the system of higher education should have evolved with a view to its improve- 
ment, their success can only be measured in quantitative terms, resultant in the foundation of several dozen universities and a similar number of conversions of one time polytechnics and colleges into universities. With the expansion of universities, there has been a corresponding rapid growth in the number of students, which, as already stated earlier, is predicted to continue. In contrast, the funding, both that paid to the centres of higher education and that paid to their students, has been reduced whilst their fees increased drastically. Fifteen years ago it was already admitted in the Dearing Report that "the expansion was [...] much faster than the government had envisaged and there was insufficient thought about the potential effects of a progressively reducing unit of funding" (Dearing 1997: 3.115). This admission seems to have gone unheeded since tampering with the system of higher education has continued. Yet subsequent steps have followed in precisely the opposite direction to that which the facts in the Dearing Report indicated in terms of action required.

Under such financial strictures, questions as to what sort of good quality education can be offered to an immense horde of students? How can academics impart knowledge, instil critical thinking, understanding and develop their enthusiasm as students rush to, tick off their modules and move to the next one with the often doubtful quality of estimated results, becomes a rhetorical question. When mass higher education is offered at least possible cost to the national budget, such problems arise, and will escalate in their intensity in the future,

On the one hand, academics are expected to produce lots of research results and teach to the best of their abilities whilst on the other hand, cuts in teaching budgets are imposed. Surely if sufficient funding was guaranteed, berating academics for prioritising research over teaching or scolding them for not providing their students with sufficient feedback, would be unnecessary. Amongst the numerous problems that have formed the present trends, especially those implemented by these 'newer and less prestigious universities', one thing appears to be common to both categories of university: chronic under-funding.

So long as these fundamental problems remain, any/all future reports on the state of higher education will inevitably have to take into account the current problems outlined in this paper. Should they not be resolved fast, they will multiply and corrode the entire creaking fractured system. Such a failure to fulfill our duty to the young of today, will have disastrous consequences and ramifications. And little consolation will be that other universities in Europe have shared the same fate. 


\section{References}

Baker S., B. Brown, Rethinking Universities, The Social Functions of Higher Education. London: Continuum International Publishing Book 2007.

Brecher B., Fast Food is No Substitute For an Intellectual Feast. The Times Higher Educational Supplement, June 7th 2002

Dearing R., Higher Education in the Learning Society. The Report of the National Committee of Inquiry into Higher Education. Norwich: HMSO 1997.

Dorey Pete, Academics do not neglect teaching for research. The Guardian, October 25, 2013.

Garner Richard, What the $£ 9,000$ fee gets you: less teaching time. The Independent, October 21, 2013.

Ginkel Hans Van, University 2050: The Organisation of Creativity and Innovation [in:] Universities in the Twenty-first Century. London: Latimer Trend and Company Ltd. 1994.

Gombrich F. Richard, British Higher Education Policy in the last Twenty Years:

The Murder of a Profession. Tokyo 2000 available from http://indology.info/papers/gombrich/ uk-higher-education.pdf retrieved May 2015.

Graham Georgia, Universities need to grow by $25 \mathrm{pc}$ to meet demand, says minister. The Daily Telegraph, October 21, 2013.

Hunt Sally, Academics do not neglect teaching for research. The Guardian, October 25, 2013.

Hussey T., P. Smith, The Trouble with Higher Education. A Critical Examination of our Universities. Abingdon: Routledge 2010.

Smoluk Marek, Current Expansion and Distortion of Higher Education in the United Kingdom, [in:]

D. Fuchs, W. Klepuszewski (ed.) Academic Fiction Revisited. Selected Essays. Koszalin: Wydawn ictwo Uczelniane Politechniki Koszalińskiej, 2014, s. 17-24 